УДК $331.52+631.147$

DOI: $10.15673 /$ fie.v12i4.1916

\author{
Нікішина О.В. \\ доктор економічних наук, старший науковий співробітник \\ завідувач відділу ринкових механізмів та структур \\ Інститут проблем ринку та економіко-екологічних досліджень НАН України \\ Французький бульвар, 29, м. Одеса, Україна, 65044 \\ E-mail: ksenkych@gmail.com \\ ORCID ID: 0000-0002-7172-3551
}

\title{
МЕТОДИЧНІ РЕКОМЕНДАЦІЇ ДО КОМПЛЕКСНОЇ ОЦІНКИ ТРУДОВИХ РЕСУРСІВ СФЕРИ ПРИРОДОКОРИСТУВАННЯ УКРАЇНИ НА ЗАСАДАХ СТАЛОГО РОЗВИТКУ *
}

\begin{abstract}
Стаття присвячена обґрунтуванню методичного забезпечення комплексної оцінки трудових ресурсів сфрери природокористування України на засадах концепцій сталого розвитку та людиноцентричного підходу. Наголошено, що даний методичний базис $є$ складовою загальних методичних рекомендацій до комплексної оцінки домінант інвестиційно-інноваційної політики природокористування національної економіки. Запропоновано систему індикаторів для діагностики стану й використання трудових ресурсів крізь призму Цілей і завдань сталого розвитку держави з акцентом на структурно-секторальний вимір. На основі авторських методичних положень і рекомендацій проведено кількісно-якісну та експертну оцінку використання трудових ресурсів сфери природокористування України, що дозволило встановити сучасні тенденції та проблеми використання трудового потенціалу секторів даної сфери. На підставі результатів комплексної оцінки обґрунтовано головні напрями і шляхи підвищення ефективності використання трудових ресурсів сфери природокористування, які одночасно сприятимуть реалізації соціальноекологічних пріоритетів інвестиційно-інноваційної політики природокористування в українських реаліях.

Ключові слова: природокористування, трудові ресурси, комплексна оцінка, сектори економіки, сталий розвиток, інвестиційно-інноваційна політика.
\end{abstract}

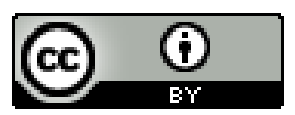

This work is licensed under a Creative Commons Attribution 4.0 International License http://creativecommons.org/licenses/by/4.0/
Постановка проблеми та їі зв'язок з важливими науковими та практичними завданнями. Завдання сталого використання природно-ресурсного потенціалу економіки, зниження ії екологічної ємності, підвищення екологічних аспектів якості життя населення в умовах системної кризи обумовлюють необхідність впровадження сучасної моделі інвестиційно-інноваційної політики природокористування (далі - ІІПП) на основі провідних міжнародних практик. Новітня модель ІІПП формується шляхом конвергенції екологічної, інвестиційної, інноваційної та соціальної політик, узгодження їх стратегічних пріоритетів та реалізується на мікро-, мезо- та макрорівнях.

Невід'ємною складовою ІІПП $є$ соціальна складова, що передбачає комплексну оцінку використання трудових ресурсів сфери природокористування на засадах сталого розвитку. Сфера природокористування України включає чотири сектори економіки: аграрний - сільське, лісове та рибне господарство, i три промислових сектори - добувна промисловість і розроблення кар'єрів; постачання електроенергії, газу, пари та кондиційованого повітря; водопостачання; каналізація, поводження 3 відходами. Окрім природно-ресурсного потенціалу, сфера природокористування має вагомий трудовий потенціал, оцінка якого в координатах сталого розвитку держави обумовлює необхідність розширення діючого методичного забезпечення. 3 іншого боку, діагностику сталого використання компонентів природно-ресурсного потенціалу економіки доцільно здійснювати крізь призму розвитку продуктивних сил, у т.ч. трудових ресурсів сфери природокористування, що актуалізує наукові дослідження даного спрямування. Їх проблематика органічно пов'язана з інститутами сталого розвитку, зокрема, програмою впровадження Цілей сталого розвитку до 2030 р., проголошених резолюцією Генеральної Асамблеї ООН № 70/1 від 25.09.2015 p. [1], Указом Президента України №722/2019 від 30.09.2019 p. [2].

Аналіз останніх публікацій по проблемі. Комплексна оцінка використання трудових ресурсів сфери природокористування базується на методичних положеннях моніторингу Цілей сталого розвитку (да$л i-Ц С Р)$ в Україні [3].

* Публікацію підготовлено в межах НДР «Домінанти інвестиційно-інноваційної політики природокористування національної економіки» за рахунок коштів бюджетної програми «Підтримка розвитку пріоритетних напрямів наукових досліджень» (КПКВК 6541230). 
Так, деякі індикатори для оцінки результативності впровадження ЦСР 8 «Гідна праця та економічне зростання», зокрема, завдань 8.2. «Підвищувати ефективність виробництва на засадах сталого розвитку та розвитку високотехнологічних конкурентних виробництв» та 8.5. «Сприяти забезпеченню надійних та безпечних умов праці для всіх працюючих, зокрема шляхом застосування інноваційних технологій у сфері охорони праці та промислової безпеки» [3, с. 62-63] можуть бути використані для оцінки сталого використання трудових ресурсів сфери природокористування. Водночас проведення діагностики сучасних тенденцій зайнятості і рівня оплати праці в сфері природокористування визначає доцільність доповнення існуючого методичного забезпечення новими секторальними індикаторами.

У вітчизняній літературі наявні дослідження стану трудових ресурсів передусім аграрного сектору економіки $[4,5]$. Так, на думку В.Я. Амбросова, співвідношення між матеріально-технічними, трудовими та природними ресурсами, їх кількісно-якісний склад та рівень віддачі визначають у сукупності величину природно-ресурсного потенціалу кожного суб'єкта агропромислового виробництва [5]. Водночас поза увагою науковців залишаються промислові сектори сфери природокористування, що не дозволяє здійснити всебічну оцінку стану іiі трудових ресурсів. На думку О.А. Жигуліна, нині в агросфері України домінує оптимізаційно-технологічний підхід до управління конкурентоспроможністю суб'єктів господарювання, який не передбачає збереження родючості земельних ресурсів й життя людей на сільських територій. У світі переважає людиноиентричний підхід, орієнтова- ний на розвиток людини і впровадження інформаційних технологій в процес кооперації та міжсуб'єктних взаємодій [6]. Саме людиноцентричний підхід дозволить реалізувати екологічні та соціальні пріоритети ІІПП в Україні, обумовлюючи доцільність розробки методичного забезпечення для діагностики трудових ресурсів сфери природокористування. Слід зазначити, що даний методичний базис $є$ невід'ємною складовою загальних методичних рекомендацій до комплексної оцінки домінант ІІПП, розроблених фахівцями Інституту проблем ринку та економікоекологічних досліджень НАН України [7].

Формулювання цілей дослідження. Мета статті - розробка методичного забезпечення комплексної оцінки трудових ресурсів сфери природокористування у координатах сталого розвитку держави, їх апробація в державному вимірі, встановлення ключових проблем раціонального використання трудових ресурсів і шляхів їх подолання в українських реаліях.

Виклад основних результатів та їх обгрунтування. Система індикаторів для оцінки використання трудових ресурсів сфери природокористування на засадах сталого розвитку наведена в таблиці 1. Авторський внесок у дану систему визначається групою індикаторів за такими напрямами, як динаміка кількості зайнятих у розрізі складових секторів сфери природокористування, динаміка їх номінальної заробітної плати та їі відхилення від середнього рівня по економіці та ін. Слід зазначити, що оцінка раціонального використання трудових ресурсів сфери природокористування $\epsilon$ малодослідженим напрямом, що свідчить про новизну методичного підходу.

Таблиця 1

Методичні рекомендації до оцінки використання трудових ресурсів сфери природокористування на засадах сталого розвитку

\begin{tabular}{|c|c|}
\hline ЦСР, Завдання сталого розвитку & Індикатори \\
\hline $\begin{array}{c}\text { ЦСР } 8 \text { «Гідна праця та економічне } \\
\text { зростання»: } \\
\text { Завдання 8.3. «Підвищити рівень за- } \\
\text { йнятості населення» }\end{array}$ & $\begin{array}{l}\text { 1. Індекс кількості зайнятих у сфері природокористування (загаль- } \\
\text { ний і за секторами), \% до } 2015 \text { р. ** } \\
\text { 2. Частка зайнятих у сфері природокористування в загальній кіль- } \\
\text { кості зайнятих в економіці, \%** } \\
\text { 3. Індекс середньооблікової кількості штатних працівників проми- } \\
\text { слових секторів сфери природокористування (загальний і за сек- } \\
\text { торами), \% до } 2015 \text { р. ** } \\
\text { 4. Частка штатних працівників промислових секторів сфери при- } \\
\text { родокористування у загальній кількості штатних працівників } \\
\text { промисловості, \%** } \\
\text { 5. Індекс номінальної заробітної плати працівників сфери приро- } \\
\text { докористування (загальний і за секторами), \% до } 2015 \text { р. ** } \\
\text { 6. Номінальна заробітна плата працівників сфери природокористу- } \\
\text { вання, у \% до середнього рівня по економіці (загальна і за сек- } \\
\text { торами)** }\end{array}$ \\
\hline $\begin{array}{c}\text { ЦСР 8: Завдання 8.5. «Сприяти забез- } \\
\text { печенню надійних та безпечних умов } \\
\text { праці для всіх працюючих, зокрема } \\
\text { шляхом застосування інноваційних } \\
\text { технологій у сфері охорони праці та } \\
\text { промислової безпеки» }\end{array}$ & $\begin{array}{l}\text { 7. Частка працівників сфери природокористування, зайнятих на } \\
\text { роботах зі шкідливими умовами праці, у загально обліковій кі- } \\
\text { лькості штатних працівників, \% }\end{array}$ \\
\hline
\end{tabular}


Продовження табл. 1

\begin{tabular}{|c|c|}
\hline ЦСР, Завдання сталого розвитку & Індикатори \\
\hline $\begin{array}{c}\text { ЦСР 8: Завдання 8.2. «Підвищувати } \\
\text { ефективність виробництва на засадах } \\
\text { сталого розвитку та розвитку високо- } \\
\text { технологічних конкурентних вироб- } \\
\text { ництв }\end{array}$ & $\begin{array}{l}\text { 8. Темп зростання продуктивності праці, \% до попереднього року } \\
\text { 9. Темп зростання продуктивності праці секторів сфери природо- } \\
\text { користування, \% до попереднього року }\end{array}$ \\
\hline $\begin{array}{c}\text { ЦСР } 2 \text { «Подолання голоду, розвиток } \\
\text { сільського господарства»: } \\
\text { Завдання 2.2. «Підвищити вдвічі про- } \\
\text { дуктивність сільського господарства, } \\
\text { насамперед за рахунок використання } \\
\text { інноваційних технологій» }\end{array}$ & $\begin{array}{l}\text { 10. Продуктивність праці в сільському господарстві, тис. дол. США } \\
\text { на } 1 \text { зайнятого }\end{array}$ \\
\hline
\end{tabular}

* Розроблено автором на основі джерела [3]

** Індикатори запропоновано автором

Використовуючи запропоноване методичне забезпечення (див. табл. 1), проведемо комплексну оцінку використання трудових ресурсів сфери приро- докористування України. Динаміка показників зайнятості у сфері природокористування наведена в таблиці 2.

Таблиця 2

Динаміка кількості зайнятих у сфері природокористування України, тис. осіб*

\begin{tabular}{|c|c|c|c|c|c|c|c|}
\hline \multirow{2}{*}{ Сектори економіки } & \multicolumn{6}{|c|}{ Роки } & \multirow{2}{*}{$\begin{array}{l}2018 \text { р. до } \\
2015 \text { р., } \%\end{array}$} \\
\hline & 2013 & 2014 & 2015 & 2016 & 2017 & 2018 & \\
\hline Усього, в. т.ч.: & 20404,1 & 18073,3 & 16443,2 & 16276,9 & 16156,4 & 16360,9 & $\mathbf{9 9 , 5 0}$ \\
\hline $\begin{array}{l}\text { 1.Сільське, лісове та рибне гос- } \\
\text { подарство }\end{array}$ & 3577,5 & 3091,4 & 2870,6 & 2866,5 & 2860,7 & 2937,6 & 102,33 \\
\hline у\% до загальної кількості & 17,53 & 17,10 & 17,46 & 17,61 & 17,71 & 17,96 & $X$ \\
\hline 2.Промисловість & 3274,8 & 2898,2 & 2573,9 & 2494,8 & 2440,6 & 2426 & 94,25 \\
\hline у\% до загальної кількості & 16,05 & 16,04 & 15,65 & 15,33 & 15,11 & 14,83 & $\mathrm{X}$ \\
\hline $\begin{array}{l}\text { 2.1. Добувна промисловість і } \\
\text { розроблення кар'єрів }\end{array}$ & 429,2 & 359,8 & 261,4 & 239,1 & 220,5 & 209,4 & 80,11 \\
\hline у\% до загальної кількості & 2,10 & 1,99 & 1,59 & 1,47 & 1,36 & 1,28 & $\mathrm{X}$ \\
\hline 2.2. Переробна промисловість & 2275,5 & 2022,2 & 1839,3 & 1791,7 & 1774,9 & 1786,3 & 97,12 \\
\hline $\begin{array}{l}\text { 2.3. Сектори енерго- та водопо- } \\
\text { стачання (2-2.2) }\end{array}$ & 570,1 & 516,2 & 473,2 & 464 & 445,2 & 430,3 & 90,93 \\
\hline у\% до загальної кількості & 2,79 & 2,86 & 2,88 & 2,85 & 2,76 & 2,63 & $X$ \\
\hline $\begin{array}{l}\text { 3. Сфера природокористуван- } \\
\text { ня }(\mathbf{1}+2.1+2.3)\end{array}$ & 4576,8 & 3967,4 & 3605,2 & 3569,6 & 3526,4 & 3577,3 & 99,23 \\
\hline у\% до загальної кількості & 22,43 & 21,95 & 21,93 & 21,93 & 21,83 & 21,86 & $\mathrm{X}$ \\
\hline
\end{tabular}

*Розраховано автором за даними Державної служби статистики України $[8,9]$

У 2018 р. у сфері природокористування України було зайнято 3577,3 тис. осіб, що склало $21,9 \%$ від загальної кількості зайнятих в економіці (див. табл. 2). Найбільша кількість зайнятих в аграрному секторі - 2937,6 тис. осіб або 18 \% від державного показника; у промислових секторах сфери природокористування кількість зайнятих $є$ значно меншою i складає 3,91 \% від загальної кількості зайнятих в економіці. У секторальній структурі зайнятих сфери природокористування 82,1% припадає на сільське господарство, 5,9\% - на добувну промисловість, $12 \%$ - на сектори енерго- і водопостачання (рис. 1). За 2013-2018 рр. відбулися структурні зміни в напря- мі зростання частки зайнятих в агросекторі (на 3,95\%) на фоні скорочення питомої ваги зайнятих у промислових секторах, передусім у добувній промисловості (на $3,53 \%$ ).

У 2018 р. порівняно 32015 р. загальна кількість зайнятих у національній економіці скоротилася на $0,5 \%$, у сфері природокористування - на 0,77\% (див. табл. 2). Більш глибоким порівняно з середнім рівнем було зменшення кількості зайнятих у добувній промисловості (на 19,9\%) та у секторах енерго- й водопостачання (на 9,1\%), що обумовлено, зокрема, зниженням їх обсягів виробництв. В аграрному секторі відбувся приріст кількості зайнятих на 2,33\%. 


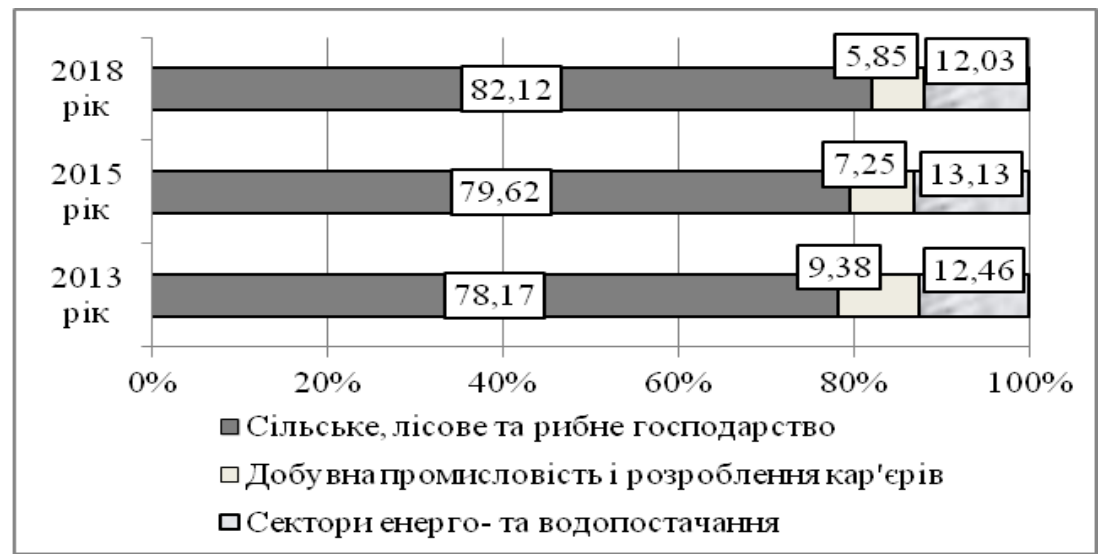

Рис. 1. Секторальна структура зайнятих у сфері природокористування Украӥни, \%*

*побудовано за даними табл. 2.

Наявність статистичного спостереження за середньообліковою кількістю штатних працівників у промисловості України дозволяє розрахувати відповідні індикатори за промисловими секторами сфери природокористування (таблиця 3). У 2018 р. кількість штатних працівників у промисловості зменшилася порівняно з 2015 р. на 9,3\%, у сфері природокорис- тування темп скорочення був вищим і склав 13,9\%. У секторальному вимірі найвищий темп скорочення був характерний для добувної промисловості (21\%) та енергосектору (12,3\%); частка вказаних секторів у загальній кількості штатних працівників промисловості скоротилася за 2013-2018 pр. 3 15,8 \% до $11 \%$ та 3 14,9 \% до 15,5 \% відповідно.

Таблиця 3

Динаміка середньооблікової кількості штатних працівників у промислових секторах сфери природокористування України, тис. осіб*

\begin{tabular}{|c|c|c|c|c|c|c|c|}
\hline \multirow{2}{*}{ Види промислової діяльності } & \multicolumn{6}{|c|}{ Роки } & \multirow{2}{*}{$\begin{array}{l}2018 \text { р. до } \\
2015 \text { р., \% }\end{array}$} \\
\hline & 2013 & 2014 & 2015 & 2016 & 2017 & 2018 & \\
\hline Промисловість, усього, в т.ч.: & 2673 & 2297 & 2040 & 1960 & 1894 & 1851 & 90,7 \\
\hline $\begin{array}{l}\text { 1. Добувна промисловість і розро- } \\
\text { блення кар'єрів }\end{array}$ & 421 & 309 & 255 & 232 & 213 & 202 & 79,2 \\
\hline у\% до загальної кількості & 15,75 & 13,45 & 12,50 & 11,84 & 11,25 & 10,91 & $X$ \\
\hline $\begin{array}{l}\text { 2. Постачання електроенергії, газу, } \\
\text { пари та кондиційованого повітря }\end{array}$ & 397 & 348 & 326 & 320 & 300 & 286 & 87,7 \\
\hline у\% до загальної кількості & 14,85 & 15,15 & 15,98 & 16,33 & 15,84 & 15,45 & $\mathrm{X}$ \\
\hline $\begin{array}{l}\text { 3. Водопостачання; каналізація, } \\
\text { поводження з відходами. }\end{array}$ & 142 & 129 & 119 & 115 & 116 & 115 & 96,6 \\
\hline y\% до загальної кількості & 5,31 & 5,62 & 5,83 & 5,87 & 6,12 & 6,21 & $\mathrm{X}$ \\
\hline 4. Сфера природокористування & 960 & 786 & 700 & 667 & 629 & 603 & 86,1 \\
\hline у\% до загальної кількості & 35,91 & 34,22 & 34,31 & 34,03 & 33,21 & 32,58 & $\mathrm{X}$ \\
\hline
\end{tabular}

*Розраховано автором за даними Державної служби статистики України $[8,9]$

Загалом у звітному році в сфері природокористування працювало 603 тис. штатних працівника, що склало 32,6 \% їх загальної кількості в промисловості (див. табл. 3). За досліджуваний період наявна негативна тенденція зменшення питомої ваги штатних працівників сфери природокористування у загальній їх кількості в промисловості. У секторальній структурі працівників сфери природокористування в 2018 р. 47,4 \% припадало на енергосектор, 33,5 \% добувну промисловість і розроблення кар'єрів, 19,1\% - сектор водопостачання.
Рівень середньомісячної номінальної заробітної плати штатних працівників сфери природокористування України в 2018 р. склав 9337 грн., що на $5,3 \%$ вище середнього рівня загальноекономічного показника (таблиця 4). У секторальному вимірі найвищий рівень заробітної плати працівників спостерігався в добувній промисловості і в секторі енергопостачання (на 40,5 \% і 21,7\% вище середнього рівня по економіці), найнижчий рівень - у сільському господарстві та секторі водопостачання (на 14,8 \% і $26 \%$ нижче державного показника відповідно). 
Динаміка середньомісячної номінальної заробітної плати штатних працівників сфери природокористування України, грн.*

\begin{tabular}{|c|c|c|c|c|c|c|c|}
\hline \multirow{2}{*}{ Сектори } & \multicolumn{6}{|c|}{ Роки } & \multirow{2}{*}{$\begin{array}{l}2018 \text { р. до } \\
2015 \text { р., \% }\end{array}$} \\
\hline & 2013 & 2014 & 2015 & 2016 & 2017 & 2018 & \\
\hline $\begin{array}{l}\text { Усі сектори економіки, } \\
\text { В т.ч.: }\end{array}$ & 3265 & 3480 & 4195 & 5183 & 7104 & 8865 & 211,3 \\
\hline 1.Сільське, лісове та рибне господарство & 2340 & 2556 & 3309 & 4195 & 6057 & 7557 & 228,4 \\
\hline у\% до середнього рівня & 71,7 & 73,4 & 78,9 & 80,9 & 85,3 & 85,2 & 108,1 \\
\hline $\begin{array}{l}\text { 2. Добувна промисловість і розроблення } \\
\text { кар'єрів }\end{array}$ & 5266 & 5445 & 6164 & 7426 & 9704 & 12452 & 202,0 \\
\hline y\% до середнього рівня & 161,3 & 156,5 & 146,9 & 143,3 & 136,6 & 140,5 & $\mathrm{X}$ \\
\hline $\begin{array}{l}\text { 3. Постачання електроенергії, газу, пари } \\
\text { та кондиційованого повітря }\end{array}$ & 4500 & 4885 & 5462 & 6918 & 8493 & 10790 & 197,5 \\
\hline у\% до середнього рівня & 137,8 & 140,4 & 130,2 & 133,5 & 119,6 & 121,7 & $\mathrm{X}$ \\
\hline $\begin{array}{l}\text { 4. Водопостачання; каналізація, пово- } \\
\text { дження з відходами. }\end{array}$ & 2777 & 2967 & 3498 & 4039 & 5199 & 6549 & 187,2 \\
\hline у\% до середнього рівня & 85,1 & 85,3 & 83,4 & 77,9 & 73,2 & 73,9 & $\mathrm{X}$ \\
\hline 5. Сфера природокористування & 3720,75 & 3963,25 & 4608,25 & 5644,5 & 7363,25 & 9337 & 202,6 \\
\hline у\% до середнього рівня & 114,0 & 113,9 & 109,9 & 108,9 & 103,6 & 105,3 & $\mathrm{X}$ \\
\hline
\end{tabular}

*Розраховано автором за даними Державної служби статистики України $[8,9]$

У 2018 р. порівняно $з 2015$ р. рівень номінальної заробітної плати штатних працівників усіх секторів національної економіки зріс на 111,3\%, сфери природокористування - на 102,6 \% (див. табл. 4). Найвищі темпи зростання були характерні для сільського господарства та добувної промисловості.

Одним із індикаторів, що визначає результативність впровадження завдання 8.5 «Сприяти забезпеченню надійних та безпечних умов праці для всіх працюючих, зокрема шляхом застосування іннова- ційних технологій у сфері охорони праці та промислової безпеки» ЦСР 8 в Україні, є частка працівників, зайнятих на роботах зі шкідливими умовами праці, у загальнообліковій кількості штатних працівників. Цільове значення показника на 2020 р. складає $22 \%$ [3, с. 63]. Моніторинг даного індикатора в секторальному вимірі дозволяє виокремити сферу природокористування та встановити притаманні їй особливості. Динаміка індикатора в секторальному вимірі наведена в таблиці 5.

Таблиця 5

Частка працівників сфери природокористування, зайнятих на роботах зі шкідливими умовами праці, у загальнообліковій кількості штатних працівників, \%*

\begin{tabular}{|c|c|c|c|c|}
\hline Сектори & 2015 рік $^{* * *}$ & 2017 рік & $\begin{array}{c}\text { Відхилення } \\
2010 \text { р. від } \\
\text { Ц3П (22\%) }\end{array}$ & $\begin{array}{l}\text { Зміни } \\
(2-1)\end{array}$ \\
\hline $\boldsymbol{A}$ & 1 & 2 & 3 & 4 \\
\hline Усі сектори економіки, в тому числі: & 28,9 & 28,4 & $+6,4$ & $-0,5$ \\
\hline $\begin{array}{l}\text { 1. Сільське господарство та надання пов'язаних } \\
3 \text { ним послуг }\end{array}$ & 11,2 & 12,6 & $-9,4$ & $+1,4$ \\
\hline $\begin{array}{l}\text { 2. Добувна промисловість і розроблення } \\
\text { кар’єрів }\end{array}$ & 68,7 & 67,9 & $+45,9$ & $-0,8$ \\
\hline 2.1. Добування кам’яного та бурого вугілля & 82 & 81,2 & $+59,2$ & $-0,8$ \\
\hline $\begin{array}{l}\text { 3. Постачання електроенергії, газу, пари та кон- } \\
\text { диційованого повітря }\end{array}$ & 35,2 & 34,9 & $+12,9$ & $-0,3$ \\
\hline $\begin{array}{l}\text { 4. Водопостачання; каналізація, поводження } 3 \\
\text { відходами. }\end{array}$ & 35,3 & 35,4 & $+13,4$ & $+0,1$ \\
\hline 5. Сфера природокористування & 37,6 & 37,7 & $+15,7$ & $+\mathbf{0 , 1}$ \\
\hline
\end{tabular}

*Розраховано автором за даними Державної служби статистики України [10];

** Дані збираються один раз на два роки ; ЦЗП - цільове значення показника 2020 р. 
У 2018 р. частка працівників сфери природокористування, зайнятих на роботах зі шкідливими умовами праці, склала $\mathbf{3 7 , 7} \%$, що на 15,7 \% вище цільового значення показника 2020 р. (22\%) та на $9,3 \%$ вище середнього рівня по економіці $(28,4 \%)$ (див. табл. 5).

Найвищий рівень індикатора притаманний добувній промисловості $(67,9$ \%), зокрема добування кам'яного й бурого вугілля $(81,2 \%)$, що більш ніж в три рази перевищує цільове значення показника 2020 р. Такий рівень $є$ найвищим серед всіх секторів національної економіки [9, с. 51]. Друге й третє місця в економіці посідають сектори водо- й енергопостачання із питомою вагою 35,4 \% і 34,9 \% відповідно, перевищуючи на $13 \%$ цільовий орієнтир 2020 р. У сільському господарстві індикатор досягає 12,6 \%, що на 9,4 \% нижче цільового значення показника. Відтак, три промислові сектори сфери природокористування України займають перші місця в економіці за часткою працівників, зайнятих на роботах зі шкідливими умовами праці, обумовлюючи необхідність впровадження інноваційних технологій охорони праці.

За 2015-2017 р. істотних зрушень у динаміці змін індикатора не відбулося, за винятком скорочення його рівня в добувній промисловості на $0,8 \%$ за одночасного зростання величини в сільському господарстві на 1,4 \% (рис. 2).

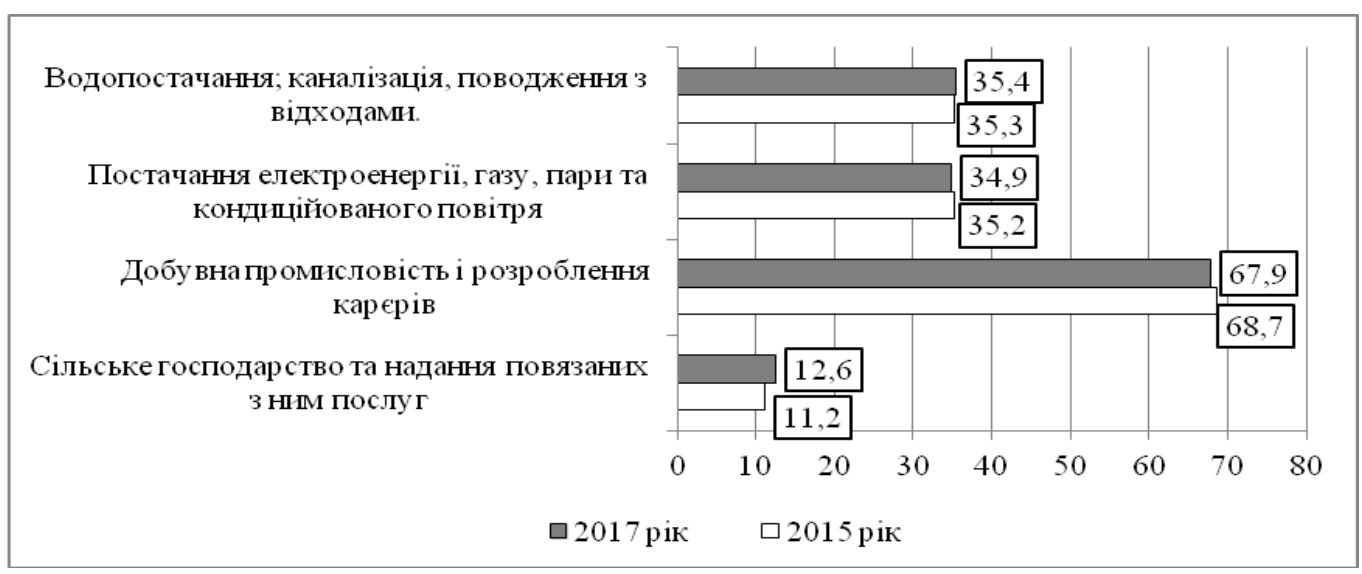

Рис. 2. Частка працівників сфери природокористування, зайнятих на роботах зі шкідливими умовами праці, \%*

* побудовано за даними табл. 5

Одним із індикаторів, що визначає результативність впровадження завдання 8.2. «Підвищувати ефективність виробництва на засадах сталого розвитку та розвитку високотехнологічних конкурентних виробництв» ЦСР 8, є індекс продуктивності праці, як загальний, так і секторальний. Його цільовим значенням на 2020 р. є $\mathbf{1 0 4} \%$, на 2030 р. - 105,8 \% [3, c. 64].

У 2018 р. продуктивність праці одного зайнятого в економіці держави складала 63,77 тис. грн. / особу (у постійних цінах 2010 р.), збільшившись порівняно з 2015 р. на $9 \%$ за рахунок зростання ВВП у постійних цінах 2010 р. на фоні скорочення кількості зайнятих. У звітному році індекс продуктивності праці всіх секторів національної економіки склав $\mathbf{1 0 2} \%$, не досягнувши цільового значення показника 2020 р. на $2 \%$ (таблиця 6). У промислових секторах сфери природокористування темп росту продуктивності праці був вищим середньодержавного рівня і склав в 2016 р. для добувної промисловості 109,7 \%, для енергосектору - 104,4 \%, не тільки досягнувши цільового орієнтиру 2020 р., а й покращивши його. Слід відзначити, що одним із чинників такої тенденції є значно вищі темпи скорочення кількості зайнятих в добувній промисловості та енергосекторі порівняно 3 середнім показником по економіці держави.

Таблиця 6

Динаміка індексів продуктивності праці зайнятих у сфері природокористування України, \%*

\begin{tabular}{|c|c|c|c|c|c|c|}
\hline \multirow{2}{*}{ Індикатори } & \multicolumn{6}{|c|}{ Роки } \\
\hline & 2013 & 2014 & 2015 & 2016 & 2017 & 2018 \\
\hline $\begin{array}{l}\text { 1. Продуктивність праці } 1 \text { зайнятого в } \\
\text { економіці, тис. грн. (у постійних цінах } \\
2010 \text { р.) }\end{array}$ & 59,06 & 58,98 & 58,49 & 60,53 & 62,49 & 63,77 \\
\hline $\begin{array}{l}\text { 2. Індекс продуктивності праці, всього, } \\
\text { \% у тому числі: }\end{array}$ & 99,7 & 99,9 & 99,2 & 103,5 & 103,2 & 102,0 \\
\hline $\begin{array}{l}\text { 2.1. Добувна промисловість і розроб- } \\
\text { лення кар'єрів }\end{array}$ & 102,5 & 114,9 & 104 & 109,7 & н.д. & н.д. \\
\hline
\end{tabular}


Продовження табл. 6

\begin{tabular}{|l|c|c|c|c|c|c|}
\hline \multicolumn{1}{|c|}{ Індикатори } & \multicolumn{5}{c|}{ Роки } & 2016 \\
\cline { 2 - 7 } & 2013 & 2014 & 2015 & 2018 & н.д. \\
\hline $\begin{array}{l}\text { 2.2. Постачання електроенергії, газу, } \\
\text { пари та кондиційованого повітря }\end{array}$ & 100,4 & 101,5 & 93,9 & $\mathbf{1 0 4 , 4}$ & н.д. \\
\hline $\begin{array}{l}\text { 3. Продуктивність праці 1 зайнятого в } \\
\text { сільському господарстві, у пост. цінах } \\
\text { 2010 року, тис. грн. }\end{array}$ & 201,2 & 227,8 & 223,3 & 275,3 & 271,5 & 313,6 \\
\hline $\begin{array}{l}\text { 4. Індекс продуктивності праці в сільсь- } \\
\text { кому господарстві, \% }\end{array}$ & 126,0 & 113,2 & 98,0 & 123,3 & 98,6 & $\mathbf{1 1 5 , 5}$ \\
\hline
\end{tabular}

*Складено за даними Мінекономрозвитку [11] та Державної служби статистики України [8]

Продуктивність праці на одного зайнятого $є$ одним із індикаторів результативності впровадження завдання 2.2. «Підвищити вдвічі продуктивність сільського господарства, насамперед за рахунок використання інноваційних технологій» ЦСР 2 «Подолання голоду, розвиток сільського господарства». Цільове значення індикатора на 2020 р. складає 10 тис. дол. США / особу, на 2025 рік - 12,5 тис. дол. США / особу [3, c. 20-21].

У 2018 р. продуктивність праці в сільському господарстві досягла 313,6 тис. грн. / особу у постійних цінах 2010 р., збільшившись порівняно з 2015 р. на 40,4 \% (див. табл. 6). Слід зазначити, що індекс продуктивності праці в аграрному секторі (115,5 \%) є значно вищим аналогічних показників у промислових секторах сфери природокористування. У 2018 р. продуктивність праці в сільському господарстві України склала $\mathbf{1 0 , 8 9}$ тис. дол. США / особу [3, с. 18], не тільки досягнувши, а й перевищивши цільове значення показника 2020 р. Одним із чинників такого зростання стало збільшення обсягів сільськогосподарського виробництва у звітному році на 8,1\% [8].

Суб'єкти господарювання сфери природокористування $\epsilon$ вагомим інвестором природоохоронних заходів в Україні, питома вага даної сфери у сукупних витратах на охорону природного середовища в 2018 р. склала $60,6 \%$ (таблиця 7). У секторальній структурі екоінвестицій домінують сектор водопостачання (23,9\%) та добувна промисловість (22,6 \%), зокрема добування металевих руд $(21,1 \%)$; їх частки за 2015-2018 pp. мають зростаючий тренд. Частка аграрного сектору є незначною (1,2\%). Знижувальна динаміка екоінвестицій притаманна сектору енергопостачання. У 2018 р. порівняно з 2015 р. обсяг екоінвестицій сфери природокористування зріс на $31,8 \%$, при цьому найбільший приріст спостерігався у секторі водопостачання (на 70,5\%).

Таблиця 7

\section{Динамічно-структурні зміни сукупних витрат на охорону навколишнього природного} середовища сфери природокористування України, млн. грн."

\begin{tabular}{|c|c|c|c|c|c|}
\hline \multirow{2}{*}{ Види економічної діяльності } & \multicolumn{4}{|c|}{ Роки } & \multirow{2}{*}{$\begin{array}{l}2018 \text { p. у \% до } \\
2015 \text { p. }\end{array}$} \\
\hline & 2015 & 2016 & 2017 & 2018 & \\
\hline Усі сектори економіки & 24591,1 & 32488,7 & 31492 & 34392,3 & 139,9 \\
\hline 1. Сільське, лісове та рибне господарство & 348,5 & 367,1 & 429 & 418,1 & 120,0 \\
\hline $\begin{array}{l}\text { 2. Добувна промисловість і розроблення } \\
\text { кар'єрів }\end{array}$ & 5222,1 & 5192,9 & 5968 & 7780,2 & 149,0 \\
\hline 2.1. у т.ч. добування металевих руд & 4864 & 4722,2 & 5569,7 & 7269,8 & 149,5 \\
\hline $\begin{array}{l}\text { 3. Постачання електроенергії, газу, пари } \\
\text { та кондиційованого повітря }\end{array}$ & 5423,5 & 9605,1 & 6148,7 & 4423,9 & 81,6 \\
\hline $\begin{array}{l}\text { 4. Водопостачання; каналізація, пово- } \\
\text { дження з відходами, всього, у т.ч. }\end{array}$ & 4816,4 & 6094,6 & 6523,3 & 8212,4 & 170,5 \\
\hline 5. Усього сфера природокористування & 15810,5 & 21259,7 & 19069 & 20834,6 & 131,8 \\
\hline \multicolumn{5}{|c|}{ Секторальна структура екоінвестицій, \% } & $\begin{array}{c}\text { Динаміка змін } \\
(+,-) \\
\end{array}$ \\
\hline 1. Сільське, лісове та рибне господарство & 1,4 & 1,1 & 1,4 & 1,2 & $-0,2$ \\
\hline $\begin{array}{l}\text { 2. Добувна промисловість і розроблення } \\
\text { кар'єрів }\end{array}$ & 21,2 & 16,0 & 19,0 & 22,6 & $+1,4$ \\
\hline 2.1. у т.ч. добування металевих руд & 19,8 & 14,5 & 17,7 & 21,1 & $+1,4$ \\
\hline $\begin{array}{l}\text { 3. Постачання електроенергії, газу, пари } \\
\text { та кондиційованого повітря }\end{array}$ & 22,1 & 29,6 & 19,5 & 12,9 & $-9,2$ \\
\hline
\end{tabular}


Продовження табл. 7

\begin{tabular}{|c|c|c|c|c|c|}
\hline \multirow{2}{*}{ Види економічної діяльності } & \multicolumn{4}{|c|}{ Роки } & \multirow{2}{*}{$\begin{array}{c}2018 \text { р. у \% до } \\
2015 \text { р. }\end{array}$} \\
\hline & 2015 & 2016 & 2017 & 2018 & \\
\hline Усі сектори економіки & 24591,1 & 32488,7 & 31492 & 34392,3 & 139,9 \\
\hline $\begin{array}{l}\text { 4. Водопостачання; каналізація, пово- } \\
\text { дження з відходами, всього, у т.ч. }\end{array}$ & 19,6 & 18,8 & 20,7 & 23,9 & $+4,3$ \\
\hline 5. Усього сфера природокористування & 64,3 & 65,4 & 60,6 & 60,6 & $-3,7$ \\
\hline
\end{tabular}

*Розраховано автором за даними $[8,12,13]$

Трудові ресурси сфери природокористування опосередковано впливають на інвестиційну політику сталого розвитку шляхом вибору методів використання земельних ресурсів, співвідношення внесених органічних і мінеральних добрив, впровадження відновлювального землеробства, охорони лісових ресурсів і природно-заповідного фонду тощо. Важливим завданням держави на шляху сталого розвитку $\epsilon$ впровадження адаптивних механізмів стимулювання фермерських i особистих селянських господарств, великих агропідприємств до впровадження екологічно чистих технологій і виробництв, заходів поводження $з$ відходами на всіх етапах ринкового процесу відтворення.

Якісна оцінка напряму і характеру змін індикаторів оцінки трудових ресурсів сфери природокористування на засадах сталого розвитку представлена в таблиці 8.

Таблиця 8

Якісна оцінка динаміки змін індикаторів використання трудових ресурсів сфери природокористування України"

\begin{tabular}{|c|c|c|}
\hline ІНДИКАТОРИ & $\begin{array}{c}\text { Динаміка змін: } \\
\text { зростання } \uparrow \\
\text { зменшення } \downarrow \\
\end{array}$ & $\begin{array}{c}\text { Оцінка динаміки: } \\
\text { П; Н; Б3; } \\
\text { ЦНД; ЦД, ДД } \\
\end{array}$ \\
\hline $\begin{array}{l}\text { 1.Загальний індекс кількості зайнятих у сфері природокористування, \% } \\
\text { до } 2015 \text { р. ** } \\
\text { За секторами сфери природокористування: } \\
\text { 1.1. Сільське, лісове та рибне господарство } \\
\text { 1.2. Добувна промисловість і розроблення кар'єрів } \\
\text { 1.3. Сектори енерго- та водопостачання }\end{array}$ & $\begin{array}{l}\uparrow \\
\downarrow \\
\downarrow\end{array}$ & $\begin{array}{l}\Pi \\
\mathrm{H} \\
\mathrm{H}\end{array}$ \\
\hline $\begin{array}{l}\text { 2. Частка зайнятих у сфері природокористування в загальній кількості } \\
\text { зайнятих в економіці, \%** }\end{array}$ & $\downarrow$ & Б3 \\
\hline $\begin{array}{l}\text { 3. Загальний індекс середньооблікової кількості штатних працівників } \\
\text { промислових секторів сфери природокористування, \% до } 2015 \text { p. ** } \\
\text { За промисловими секторами сфери природокористування: } \\
\text { 3.1. Добувна промисловість і розроблення кар'єрів } \\
\text { 3.2. Постачання електроенергії, газу, пари та кондиційованого повітря } \\
\text { 3.3. Водопостачання; каналізація, поводження з відходами. }\end{array}$ & $\begin{array}{l}\downarrow \\
\downarrow \\
\downarrow\end{array}$ & $\begin{array}{l}\mathrm{H} \\
\mathrm{H} \\
\mathrm{H}\end{array}$ \\
\hline $\begin{array}{l}\text { 4. Частка штатних працівників промислових секторів сфери природокори- } \\
\text { стування у загальній кількості штатних працівників промисловості, \%** } \\
\text { За промисловими секторами сфери природокористування: } \\
\text { 4.1. Добувна промисловість і розроблення кар'єрів } \\
\text { 4.2. Постачання електроенергії, газу, пари та кондиційованого повітря } \\
\text { 4.3. Водопостачання; каналізація, поводження з відходами. }\end{array}$ & $\begin{array}{l}\downarrow \\
\downarrow \\
\downarrow \\
\end{array}$ & $\begin{array}{l}\mathrm{H} \\
\text { Б3 } \\
\text { Б3 } \\
\end{array}$ \\
\hline $\begin{array}{l}\text { 5. Індекс номінальної заробітної плати працівників сфери природокорис- } \\
\text { тування (загальний і за секторами), \% до } 2015 \text { р. ** } \\
\text { За секторами сфери природокористування: } \\
\text { 5.1. Сільське, лісове та рибне господарство } \\
\text { 5.2. Добувна промисловість і розроблення кар’єрів } \\
\text { 5.3. Постачання електроенергії, газу, пари та кондиційованого повітря } \\
\text { 5.4. Водопостачання; каналізація, поводження з відходами. }\end{array}$ & $\begin{array}{l}\uparrow \\
\uparrow \\
\uparrow \\
\uparrow\end{array}$ & П; ДД \\
\hline $\begin{array}{l}\text { 6. Загальна номінальна заробітна плата працівників сфери природокори- } \\
\text { стування, у \% до середнього рівня по економіці** } \\
\text { За секторами сфери природокористування: } \\
\text { 6.1. Сільське, лісове та рибне господарство } \\
\text { 6.2. Добувна промисловість і розроблення кар'єрів } \\
\text { 6.3. Постачання електроенергії, газу, пари та кондиційованого повітря } \\
\text { 6.4. Водопостачання; каналізація, поводження з відходами. }\end{array}$ & $\begin{array}{l}\uparrow \\
\downarrow \\
\downarrow \\
\downarrow\end{array}$ & $\begin{array}{c}\text { Н } \\
\text { ДД } \\
\text { ДД } \\
\text { ДД } \\
\text { Н }\end{array}$ \\
\hline
\end{tabular}


Продовження табл.8

\begin{tabular}{|c|c|c|}
\hline ІНДИКАТОРИ & $\begin{array}{c}\text { Динаміка змін: } \\
\text { зростання } \uparrow \\
\text { зменшення } \downarrow \\
\end{array}$ & $\begin{array}{c}\text { Оцінка динаміки: } \\
\text { П; Н; БЗ; } \\
\text { ЦНД; ЦД, ДД** } \\
\end{array}$ \\
\hline $\begin{array}{l}\text { 7. Частка працівників сфери природокористування, зайнятих на робо- } \\
\text { тах зі шкідливими умовами праці, у загально обліковій кількості шта- } \\
\text { тних працівників, \% } \\
\text { За секторами сфери природокористування: } \\
\text { 7.1. Сільське, лісове та рибне господарство } \\
\text { 7.2. Добувна промисловість і розроблення кар'єрів } \\
\text { 7.3. Постачання електроенергії, газу, пари та кондиційованого повітря } \\
\text { 7.4. Водопостачання; каналізація, поводження з відходами }\end{array}$ & $\begin{array}{l}\uparrow \\
\downarrow \\
\downarrow \\
\downarrow\end{array}$ & $\begin{array}{c}\text { Б3; ЦНД } \\
\text { ЦД+ } \\
\text { П; ЦНД } \\
\text { Б3; ЦНД } \\
\text { Б3; ЦНД }\end{array}$ \\
\hline 8. Темп зростання продуктивності праці, \% до попереднього року & $\uparrow$ & П; ЦНД \\
\hline $\begin{array}{l}\text { 9. Темп зростання продуктивності праці секторів сфери природоко- } \\
\text { ристування, \% до попереднього року }\end{array}$ & $\uparrow$ & П; ЦД \\
\hline $\begin{array}{l}\text { 10. Продуктивність праці в сільському господарстві, тис. дол. США } \\
\text { на } 1 \text { зайнятого }\end{array}$ & $\uparrow$ & П; ЦД+ \\
\hline
\end{tabular}

"Складено автором на підставі даних таблиць 2-6;

** Індикатори запропоновано автором;

*** Умовні позначення: П - позитивна динаміка; Н - негативна; Б3 - без значних змін; ЦНД - цільове значення показника не досягнуто; ЦД - цільове значення показника досягнуто; ДД - оцінка потребує додаткових досліджень.

Динаміка групи індикаторів, що оцінюють рівень використання трудових ресурсів сфери природокористування, $\epsilon$ нейтральною (без значних змін) в напрямі руху до реалізації завдання 8.3 «Підвищити рівень зайнятості населення», негативною в напрямі руху до реалізації завдання 8.5 «Сприяти забезпеченню надійних та безпечних умов праці» та позитивною в напрямі зростання продуктивності праці (див. табл. 8).

Для інтегральної оцінки використання трудових ресурсів сфери природокористування крізь призму впровадження Цілей сталого розвитку використаємо метод експертних оцінок. Результати комплексної оцінки трудових ресурсів та якісної оцінки дина- міки змін цільових індикаторів формують достатнє аналітичне підгрунтя для проведення анкетування фахівців 3 питань природокористування та сталого розвитку національної економіки. Для експертної оцінки використаємо інтервальну шкалу, що включає 5 типів оцінки [7]: (1) дуже низька - 0 -0,20 бали; (2) низька - 0,21-0,35 балів; (3) середня - 0,36-0,65 бали; (4) висока середня - 0,66-0,80 бали; (5) висока 0,81-1,00 бали. За такого способу нормування рівень використання трудових ресурсів набуває значення від 0 до 1. Чим він $є$ ближчим до 1 , тим вищий ступінь реалізації завдань сталого розвитку в сфері природокористування, і навпаки.

Таблиця 9

Результати експертної оцінки використання трудових ресурсів сфери природокористування України на засадах сталого розвитку*

\begin{tabular}{|c|c|c|c|c|}
\hline \multirow{2}{*}{ ЦСР і завдання } & \multicolumn{2}{|c|}{ Рівень використання } & \multirow{2}{*}{$\begin{array}{r}\text { Коефіціснт } \\
\text { вагомості }\end{array}$} & \multirow{2}{*}{$\begin{array}{l}\text { Інтегральна } \\
\text { оцінка }\end{array}$} \\
\hline & $\begin{array}{l}\text { Бальна } \\
\text { оцінка }\end{array}$ & $\begin{array}{l}\text { Якісна } \\
\text { оцінка }\end{array}$ & & \\
\hline $\begin{array}{l}\text { 1.ЦСР 8: Завдання 8.3. «Підвищити рівень за- } \\
\text { йнятості населення» }\end{array}$ & 0,45 & Середній & 0,25 & 0,113 \\
\hline $\begin{array}{l}\text { 2. ЦСР 8: Завдання 8.5. «Сприяти забезпечен- } \\
\text { ню надійних та безпечних умов праці для всіх } \\
\text { працюючих» }\end{array}$ & 0,20 & $\begin{array}{c}\text { Дуже } \\
\text { низький }\end{array}$ & 0,27 & 0,054 \\
\hline $\begin{array}{l}\text { 3. ЦСР 8: Завдання 8.2. «Підвищувати ефекти- } \\
\text { вність виробництва на засадах сталого розвитку }\end{array}$ & 0,66 & $\begin{array}{l}\text { Високий } \\
\text { середній }\end{array}$ & 0,24 & 0,158 \\
\hline $\begin{array}{l}\text { 4. ЦСР 2: Завдання 2.2. «Підвищити вдвічі } \\
\text { продуктивність сільського господарства }\end{array}$ & 0,81 & Високий & 0,24 & 0,194 \\
\hline УСЬОГО & $X$ & $X$ & 1 & $\begin{array}{c}\mathbf{0 , 5 1 9} \\
\text { Середній }\end{array}$ \\
\hline
\end{tabular}

*Узагальнені результати експертного опитування 
На підставі результатів кількісно-якісної оцінки (див. табл. 2-8) рівень раціонального використання трудових ресурсів сфери природокористування експертами оцінено як середній $(0,519)$ (таблиця 9). При цьому найменші значення отримали такі завдання, як «Сприяти забезпеченню надійних та безпечних умов праці для всіх працюючих» $(0,20$ - дуже низький) та «Підвищити рівень зайнятості населення» $(0,45$ - середній $)$, маючи при цьому більш високі коефіцієнти вагомості.

Висновки та перспективи подальших досліджень. У ході дослідження розроблено методичне забезпечення комплексної оцінки використання трудових ресурсів сфери природокористування на засадах сталого розвитку. Наголошено на взаємозв'язку даного методичного базису із людино-центричним підходом до управління конкурентоспроможністю суб'єктів господарювання, який у сучасних умовах інформаційного суспільства домінує в розвинених країнах. Використовуючи запропоновані методичні положення та рекомендації, проведено кількісноякісну та експертну оцінку використання трудових ресурсів сфери природокористування України, на підставі якої встановлено низку негативних тенденцій у реалізації іiі трудового потенціалу, а саме: (1) незначне скорочення кількості зайнятих у сфері природокористування (найвищий темп зниження притаманний добувній промисловості - 20\%); (2) нижчі рівні заробітної плати працівників у сільському господарстві та секторі водопостачання порівняно 3 державним показником (на $15 \%$ і $26 \%$ ); (3) висока частка працівників сфери, зайнятих на роботах зі шкідливими умовами праці (38\%), особливо в добувній промисловості (68\%). У звітному році індекси продуктивності праці секторів сфери природокористування досягли цільових орієнтирів сталого розвитку 2020 р. Експертна оцінка стану використання трудових ресурсів даної сфери є середньою, при цьому найнижчий рівень впровадження характерний для завдання 8.5. «Сприяти забезпеченню надійних та безпечних умов праці для всіх працюючих» ЦСР 8.

Для забезпечення подальшого прогресу в досягненні ЦСР 8 «Гідна праця та економічне зростання» в сфері природокористування України доцільним $\epsilon$ впровадження інноваційних технологій у галузі охорони праці для створення безпечних умов праці для зайнятих працівників; реалізація комплексу заходів щодо ефективного використання трудових ресурсів та підвищення продуктивності праці; застосування сучасних методів стимулювання та мотивації для підвищення зацікавленості працівників у результативності діяльності підприємств природоохоронної сфери; розробка та впровадження стратегії інклюзивного розвитку, яка $є$ необхідною умовою сталого відтворювального розвитку національної економіки на інноваційній основі. Також важливим напрямом реалізації соціальних та екологічних домінант ІІПП $є$ стимулювання впровадження суб'єктами господарювання, у т.ч. сфери природокористування, екологічно чистих, ресурсоефективних виробництв та екоінновацій, зокрема екологічної модернізації промислових підприємств, шляхом зниження ставки екологічного податку, або у формі фіксованої річної суми компенсації, що передбачено Законом «Про Основні засади (стратегію) державної екологічної політики України на період до 2020 р.» №2697-VII [14]. Очікується, що екологічна модернізація суб'єктів господарювання сфери природокористування позитивно вплине на продуктивність праці та умотивованість діяльності їх працівників, на безпечність умов праці.

Наукова новизна проведеного дослідження полягає в розвитку методичного забезпечення до комплексної оцінки використання трудових ресурсів сфери природокористування, як складової діагностики соціальних пріоритетів ІІПП, на засадах концепції сталого розвитку та людиноцентричного підходу до управління конкурентоспроможністю суб'єктів і секторів економіки. Прикладне значення отриманих результатів визначається можливістю їх використання державними і профільними інституціями, суб'єктами господарювання та іншими стейкхолдерами в ході визначення сучасних трендів і проблем використання трудового потенціалу, як аналітичного підгрунтя для розробки адаптивних механізмів реалізації соціальних пріоритетів ІІПП в українських реаліях. Перспективи подальших досліджень полягають у доповненні комплексної системи індикаторів новими показниками для оцінки рівня розвитку трудових ресурсів та впровадження інноваційно-інформаційних технологій на засадах людиноцентричного підходу.

\section{Література}

1. Цілі Сталого розвитку 2016-2030. URL: http://www.un.org.ua/ua/tsili-rozvytku-tysiacholittia/tsilistaloho-rozvytku (дата звернення 11.10.2020).

2. Про Цілі сталого розвитку України на період до 2030 року: Указ Президента України від 30 вересня 2019 р. № 722/2019. URL: https://zakon.rada.gov.ua/laws/show/722/2019 (дата звернення 11.10.2020).

3. Цілі Сталого Розвитку: Україна: Національна доповідь 2017. Київ: Міністерство економічного розвитку і торгівлі України, 2017. 176 с.

4. Мазур Г.Ф. Природно-ресурсний потенціал розвитку агропромислового виробництва // Економіка АПК. 2013. №10. С.80-86.

5. Амбросов В.Я. Ефективність використання факторів розширеного відтворення в аграрному секторі // Економіка України. 2009. №1. С.67-73.

6. Жигулін О.А. Людино-центричний підхід в управлінні конкурентоспроможністю сільськогосподарських підприємств // Економіка АПК. 2018. №10. С.57-63. doi: 10.32317/2221-1055.201810057 
7. Буркинський Б.В., Нікішина О.В. Методичні рекомендації до комплексної оцінки домінант інвестиційно-інноваційної політики природокористування національної економіки: наук. доповідь. Одеса: ІПРЕЕД НАН України, 2020. 195 с.

8. Офіційний сайт Державної служби статистики України. URL: http://www.ukrstat.gov.ua/ (дата звернення 11.10.2020).

9. Статистичний щорічник України за 2018 рік / за ред. I.С.Вернера. Київ: Державна служба статистики України, 2019.482 с.

10. Цілі сталого розвитку Україна 2019 р.: моніторинговий звіт. Київ: Державна служба статистики України, ЮНІСЕФ. 92 с.

11. Продуктивність праці та продуктивність капіталу. Київ: Міністерство економічного розвитку та торгівлі України, 2018. 12 с.

12. Довкілля України за 2018 рік: статистичний збірник / за ред. О. М. Прокопенко. Київ: Державна служба статистики України, 2019. 214 с.

13. Нікішина О.В. Теоретико-методичні положення щодо комплексної оцінки домінант інвестиційноінноваційної політики природокористування України // Економіка харчової промисловості. 2020. Т.12, вип. 3. C. 66-80. doi: 10.15673/fie.v12i3.1818

14. Про Основні засади (стратегію) державної екологічної політики України на період до 2030 року: Закон України № 2697-VII від 28.02.2019 p. за станом на 01.01.2020. URL: https://zakon.rada.gov.ua/laws/show/2697-19\#Text (дата звернення 11.10.2020).

Стаття надійшла 26.10.2020

Стаття прийнята до друку 9.11.2020 Доступно в мережі Internet 29.12.2020

\author{
Никишина О.В. \\ доктор экономических наук, старший научный сотрудник, \\ заведующий отделом рыночных механизмов и структур \\ Институт проблем рынка и экономико- \\ экологических исследований НАН Украины \\ Французский бульвар, 29, г. Одесса, Украина, 65044 \\ E-mail: ksenkych@gmail.com. \\ ORCID ID: 0000-0002-7172-3551
}

\title{
МЕТОДИЧЕСКИЕ РЕКОМЕНДАЦИИ К КОМПЛЕКСНОЙ ОЦЕНКЕ ТРУДОВЫХ РЕСУРСОВ СФЕРЫ ПРИРОДОПОЛЬЗОВАНИЯ УКРАИНЫ НА ОСНОВЕ УСТОЙЧИВОГО РАЗВИТИЯ
}

\begin{abstract}
Статья посвящена обоснованию методического обеспечения для комплексной оценки трудовых ресурсов сферы природопользования Украины на основе концепций устойчивого развития и человекоцентричного подхода. Данный методический базис является составной общих методических рекомендаций к комплексной оценке доминант инвестиционно-инновационной политики природопользования национальной экономики, разработанных учеными Института проблем рынка и экономико-экологических исследований НАН Украины. Предложена система индикаторов для диагностики состояния и использования трудовых ресурсов сквозь призму Целей и задач устойчивого развития государства с акцентом на структурно-секторальное измерение.

На основании авторских методических положений и рекомендаций проведены количественнокачественная и экспертная оценки использования трудовых ресурсов сферы природопользования Украины в 2013-2018 годах. Определены современные тенденции и проблемы использования трудового потенциала секторов данной сореры, в частности: (1) сокращение количества занятых в сорере природопользования, кроме аграрного сектора; (2) более низкий уровень заработной платы работников в сельском хозяйстве и секторе водоснабжения по сравнению с государственным показателем; (3) высокая доля работников сореры, занятых на работах с вредными условиями труда, особенно в добывающей промышленности. В отчетном году индексы производительности труда секторов сферы природопользования достигли целевых ориентиров устойчивого развития 2020 г. Экспертная оценка состояния использования трудовых ресурсов данной сферы является средней.

На основании результатов комплексной оценки обоснованы главные направления и пути повышения эффективности использования трудовых ресурсов сферы природопользования Украины, в частности: (1) внедрение инновационных технологий в области охраны труда для создания безопасных
\end{abstract}


условий труда для занятых работников; (2) реализация комплекса мероприятий по эффективному использованию трудовых ресурсов и повышения производительности труда; (3) реализация стратегий инклюзивного развития в секторах экономики; (4) экологическая модернизация предприятий сферы природопользования. Внедрение данных направлений одновременно будет способствовать реализации социально-экологических приоритетов инвестиционно-инновационной политики природопользования в Украине.

Ключевые слова: природопользование, трудовые ресурсы, комплексная оценка, сектора экономики, устойчивое развитие, инвестиционно-инновационная политика.

\author{
Nikishyna 0. \\ Doctor of Economics, Senior Researcher \\ Head of Department of Market Mechanisms and Structures \\ Institute of Market Problems and Economic \& Ecological Research \\ of National Academy of Sciences of Ukraine \\ Frantsuzskiy boulevard, 29, Odesa, Ukraine, 65044 \\ E-mail: ksenkych@gmail.com \\ ORCID ID: 0000-0002-7172-3551
}

\title{
METHODICAL RECOMMENDATIONS FOR A COMPREHENSIVE ASSESSMENT OF LABOR RESOURCES IN THE FIELD OF NATURE MANAGEMENT OF UKRAINE ON THE BASIS OF SUSTAINABLE DEVELOPMENT
}

The article is devoted to the substantiation of methodical support for a comprehensive assessment of labor resources in the field of nature management in Ukraine on the basis of the concepts of sustainable development and human-centric approach. This methodological basis is a component of general methodological recommendations for a comprehensive assessment of the dominants of investment and innovation policy of nature management of the national economy, developed by the scientists of the Institute of Market Problems and Economic and Environmental Research of the NAS of Ukraine. A system of indicators for diagnosing the state and use of labor resources through the prism of the Goals and Tasks of Sustainable Development of the state with an emphasis on the structural and sectoral dimension has been proposed.

Based on the author's methodological provisions and recommendations, a quantitative-qualitative and expert assessment of the use of labor resources in the field of nature management of Ukraine for 2013-2018 was conducted. The current trends and problems of using the labor potential of the sectors of this sphere have been identified, in particular: (1) reduction of the number of employees in the field of nature management, except for the agricultural sector; (2) lower levels of wages in agriculture and the water sector compared to the state figure; (3) a high proportion of workers employed in hazardous work, especially in the mining industry. In the reporting year, the labor productivity indices of the sectors of nature management reached the targets of sustainable development in 2020. Expert assessment of the condition of use of labor resources in this area is average.

Based on the results of the comprehensive assessment, the main directions and ways to increase the efficiency of labor resources in the field of nature management of Ukraine have been substantiated, in particular: (1) introduction of innovative technologies in the field of labor protection to create safe working conditions for employees; (2) implementation of a set of measures for the efficient use of labor resources and increase of labour productivity; (3) implementation of inclusive development strategies in economic sectors; (4) ecological modernization of enterprises in the field of nature management. The introduction of these areas will simultaneously contribute to the implementation of social and environmental priorities of investment and innovation policy of nature management in Ukraine.

Key words: nature management, labor resources, complex assessment, economic sectors, sustainable development, investment and innovation policy.

\section{References}

1. Tsili Staloho rozvytku 2016-2030. Retrieved October 11, 2020, from http://www.un.org.ua/ua/tsilirozvytku-tysiacholittia/tsili-staloho-rozvytku.

2. Pro Tsili staloho rozvytku Ukrainy na period do 2030 roku: Ukaz Prezydenta Ukrainy vid 30 veresnia 2019 r. № 722/2019. Verkhovna Rada Ukrainy. (2019). Retrieved October 11, 2020, from URL: https://zakon.rada.gov.ua/laws/show/722/2019

3. Tsili Staloho Rozvytku (2017). Kyiv: Ministerstvo ekonomichnoho rozvytku i torhivli Ukrainy. 
4. Mazur, H. (2013). Pryrodno-resursnyi potentsial rozvytku ahropromyslovoho vyrobnytstva. Ekonomika $A P K,(10), 80-86$.

5. Ambrosov, V. (2009). Efektyvnist vykorystannia faktoriv rozshyrenoho vidtvorennia v ahrarnomu sektori. Ekonomika Ukrainy. (1), 67-73.

6. Zhyhulin, O. (2018). Liudyno-tsentrychnyi pidkhid v upravlinni konkurentospromozhnistiu silskohospodarskykh pidpryiemstv. Ekonomika APK. (10), 57-63. doi: 10.32317/2221-1055.201810057

7. Burkynskyi, B., \& Nikishyna, O. (2020). Metodychni rekomendatsii do kompleksnoi otsinky dominant investytsiino-innovatsiinoi polityky pryrodokorystuvannia natsionalnoi ekonomiky. Odesa: IPREED NAN Ukrainy.

8. Ofitsiinyi sait Derzhavnoi sluzhby statystyky Ukrainy. Retrieved October 11, 2020, from http://www.ukrstat.gov.ua/

9. Verner, I. (Ed.). (2019). Statystychnyi shchorichnyk Ukrainy za 2018 rik. Kyiv: Derzhavna sluzhba statystyky Ukrainy.

10. Tsili staloho rozvytku Ukrainy 2019 r.: monitorynhovyi zvit. (2020). Kyiv: Derzhavna sluzhba statystyky Ukrainy, YuNISEF.

11. Produktyvnist pratsi ta produktyvnist kapitalu. (2018). Kyiv: Ministerstvo ekonomichnoho rozvytku ta torhivli Ukrainy.

12. Prokopenko, O. (Ed.). (2019). Dovkillia Ukrainy za 2018 rik. Kyiv: Derzhavna sluzhba statystyky Ukrainy.

13. Nikishyna, O. (2020). Teoretyko-metodychni polozhennia shchodo kompleksnoi otsinky dominant investytsiino-innovatsiinoi polityky pryrodokorystuvannia Ukrainy. Ekonomika kharchovoi promyslovosti, 12(3), 6680. doi: 10.15673/fie.v12i3.1818

14. Pro Osnovni zasady (stratehiiu) derzhavnoi ekolohichnoi polityky Ukrainy na period do 2030 roku: Zakon Ukrainy № 2697-VII vid 28.02.2019 r. za stanom na 01.01.2020. Verkhovna Rada Ukrainy. (2020). Retrieved October 11, 2020, from https://zakon.rada.gov.ua/laws/show/2697-19\#Text

Received 26 October 2020 Approved 9 November 2020 Available in Internet 29.12.2020

Цитування згідно ДСТУ 8302:2015

Нікішина О. В. Методичні рекомендації до комплексної оцінки трудових ресурсів сфери природокористування України на засадах сталого розвитку // Економіка харчової промисловості. 2020. Т.12, вип. 4. С. 79-91. doi: 10.15673/fie.v12i4.1916

Cite as APA style citation

Nikishyna, O. (2020). Methodical recommendations for a comprehensive assessment of labor resources in the field of nature management of Ukraine on the basis of sustainable development. Food Industry Economics, 12(4), 79-91. doi: 10.15673/fie.v12i4.1916 